\title{
Lancelot Voisin de La Popelinière, L'Histoire de France. Tome II (1558-1560)
}

\section{Maurizio Busca}

\section{(2) OpenEdition}

\section{Journals}

\section{Edizione digitale}

URL: http://journals.openedition.org/studifrancesi/5287

DOI: 10.4000/studifrancesi.5287

ISSN: 2421-5856

\section{Editore}

Rosenberg \& Sellier

\section{Edizione cartacea}

Data di pubblicazione: 1 dicembre 2016

Paginazione: 516

ISSN: 0039-2944

\section{Notizia bibliografica digitale}

Maurizio Busca, «Lancelot Voisin de La Popelinière, L'Histoire de France. Tome II (1558-1560) », Studi Francesi [Online], 180 (LX | III) | 2016, online dal 01 janvier 2017, consultato il 18 septembre 2020.

URL : http://journals.openedition.org/studifrancesi/5287 ; DOI : https://doi.org/10.4000/studifrancesi. 5287

Questo documento è stato generato automaticamente il 18 settembre 2020.

\section{(c) $(1)$}

Studi Francesi è distribuita con Licenza Creative Commons Attribuzione - Non commerciale - Non opere derivate 4.0 Internazionale. 


\title{
Lancelot Voisin de La Popelinière, L'Histoire de France. Tome II (1558-1560)
}

\author{
Maurizio Busca
}

\section{NOTIZIA}

LANCELOT VOISIN DE LA POPELINIÈRE, L'Histoire de France. Tome II (1558-1560), édition critique par Jean-Claude Laborie, Benoist Pierre et Pierre-Jean souriac sous la direction de Denise Turrel, Genève, Droz, 2016, «Travaux d'Humanisme et Renaissance» DLV, 536 pp.

1 Continua l'impresa di edizione critica della monumentale Histoire de France di La Popelinière, diretta da Denise Turrel. Il primo tomo, pubblicato nel 2011, riuniva i libri I-IV preceduti da un'introduzione generale (si veda la segnalazione a cura di M. Mastroianni apparsa in «Studi Francesi»166, p. 135); questo secondo tomo riporta il testo - riccamente annotato - dei libri V e VI, dedicati agli avvenimenti degli anni 1558-1560 (nel libro $\mathrm{V}$ trova spazio anche un'ampia digressione sulle imprese dei portoghesi e dei francesi in Brasile nella prima metà del Cinquecento). La breve nota introduttiva, che si rifà a recenti ricerche di Turrel, concerne lo stabilimento del vero nome dell'autore: il prénom «Henri», che soltanto dalla metà del XIX secolo viene attribuito a La Popelinière, non trova infatti riscontri nelle fonti cinquecentesche. Imputabile alla negligenza del biografo Guyot de Fère, l'errore si è imposto col passare del tempo nei lavori degli studiosi e nei cataloghi di importanti istituzioni bibliotecarie. Si auspica che venga al più presto ripristinata, nell'uso, la forma corretta. 